\title{
The Prospect of Invention in Rhetorical Studies of Science, Technology, and Medicine
}

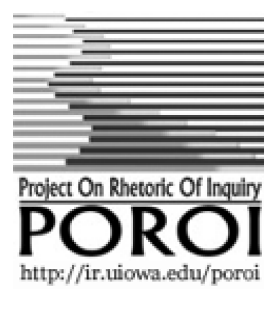

\author{
Lawrence J. Prelli \\ Department of Communication, University of New Hampshire \\ Durham, NH USA
}

Poroi 9,1 (April 2013)

In a recent essay in the Quarterly Journal of Speech, E. Johanna Hartelius (2012) argued that rhetorical invention is the foundation of distinctive intellectual and productive contributions of rhetorical studies, reiterating in a different context Charles W. Kneupper and Floyd D. Anderson's (1980) call for greater attention to invention more than three decades ago. My position is that rhetorical studies of science, technology, and medicine (hereafter, RSSTM) can be further advanced through continued study of rhetorical invention. I offer three lines of inquiry as having productive potential for that work, though without any pretention of exhaustiveness. ${ }^{1}$ Most of this paper is devoted to discussion of the invention of perspectives of or about science, technology, and medicine (hereafter, STM), followed respectively by more abbreviated discussions of the identification, analysis, and criticism of commonplaces, and of the place of a rhetorical perspective-informed by invention-in the crossdisciplinary collaborative work of STM studies.

Study of the invention of perspective includes inquiry into the creative processes and imaginative practices of figurative language in the invention of perspectives of or about STM, especially including perspectives that adduce claims that are largely taken-for-granted as proven or highly probable. Useful but surprisingly few resources are available for this work. Among them is Jeanne Fahnestock's (1999) book on classical figures in science and Hayden White's $(1973,1978,1999)$ and Kenneth Burke's (1969) work on the master tropes that presumably prefigure all thought and discourse. Fahnestock (2005a,b) initiated investigation of the relationship of the figures to work on cognitive processes in the psychological sciences, an area other scholars will likely follow. The Vichian tropes have been put to use in general analyses of discourses of and about science (Schiappa, 1993; Smith, 1996; Tietge, 1998). But it is Mark P. Moore's work on synecdoche (1993, 1996, 2003, 2009) in public discourses involving matters of science that provides the

${ }^{1}$ Invention was a major focus of rhetorical studies of science in the late 1980s (Gross, 1990; Nelson, 1987, 407-34; Prelli 1989; Simons, 1990). For a useful overview of the field as it stood nearly twenty years ago, see Campbell and Benson (1996). 
kind of detailed, specific case studies that, in my view, can enable contextgrounded disclosures of the imaginative origins of perspective and, thereby, furnish strong exemplars for work on the invention of perspective in RSSTM. Accordingly, I am at work on the invention of ecology as a science during the early decades of the twentieth century, a study that discloses a plurality of competing ecological perspectives that are separable by the tropes that prefigured them (Prelli, 2011).

The four master tropes (metaphor, metonymy, synecdoche, irony) and their prosaic counterparts (perspective, reduction, representation, dialectic) provide a useful critical framework for examining the imaginative origins of invented perspectives (Burke, 1969). Kenneth Burke's discussion of the terminological operations of the tropes and of their counterparts is well known, but less noted is that his Permanence and Change (1984b) is itself a searching and detailed case study of the trope of metaphor in relation to purportedly literal "orientations" or perspectives across a wide range of specific situations. That sort of relationship is often of rhetorical significance when data and facts become points of contention, especially in public discourses about STM. In those contexts, for example, participants can find themselves involved in the specific rhetorical dynamic of literalizing preferred metaphorical associations as factual and refiguring other purported facts as "merely" metaphorical or, otherwise, as fanciful (Prelli, 2006b). Case analyses of one or more of the tropes involved in that rhetorical dynamic could disclose the creative origins of what subsequently would become the taken-for-granted data or facts, or concepts or theories, of purportedly authoritative STM in the public domain, if not also in the technical domain.

Kenneth Burke's dramatism also can inform studies of the invention of perspective, though detailed work using dramatism in RSSTM is rare. The pentad, recalcitrance, and perspective by incongruity are useful critical concepts for identifying, differentiating, and analyzing perspectives adduced to create or respond to specific problems. The pentad enables mapping of distinct terminological starting points and their extensions to encompass a situation's meanings (Anderson \& Prelli, 2001). There are instructive exemplars of pentadic mapping and its use to identify and question perspectives that have come to dominate discourse in terms of purportedly "settled" medical science or related established policy (Beck, 2006; Meisenbach, Remke, Buzzanell, \& Liu, 2008), but more studies that explore the prospects and possibilities of this approach in RSSTM are needed. Recalcitrance, the most realistic concept within Burke's dramatistic realism, enables critics to assess the adequacy of alternative perspectives in coming to terms with, or in summing up, a situation's meaning. That assessment requires analytical disclosure of factors that "substantiate," "incite," or "correct" statements adduced from the terminological vantages of those perspectives when brought into communicative and critical contact (Burke, 1984a, 47n). Recalcitrance thus provides a seldom-used but potentially very useful critical concept for assessing perspectives-grounded in situated context-whether 
individually or in comparison with others. ${ }^{2}$ Perspective by incongruity (Burke, 1984b) is a concept that not only enables critics to trace analytically the emergence of new perspectives within a discourse, but also to invent incongruous perspectives from which to question those that have become dominant and, thus, expose them to meanings inaccessible from within their otherwise unchallenged terms. Enacting incongruous perspectives points the way toward a dialectic that brings distinctive perspectives into communicative contact and, thereby, creates opportunities for revisions, adjustments, and, perhaps, even the invention of new terminological starting points for developing more encompassing perspectives that are more adequate to their respective situations. ${ }^{3}$

The creative processes and practices involved in generating perspectives of or about STM can also be examined through a focus on argumentation. This part of the field is thriving, with some scholars (e.g., Graham \& Herndl, 2011; Prelli, 2004, 2005; and Walsh 2009, 2010) making classical precepts central to their analyses (e.g., topoi, stasis) and others exhibiting relatively more peripheral or subordinate analytical uses, if they choose to use them at all. Among the latter are authors of three book-length studies. Lynch's (2011) study examines the "scientific idiom" in public arguments about stem cell research, with attention to how "real definitions" are generated that, in turn, establish purported facts about stem cells. Keränen's (2010) work analyzes the contested personae of medical researchers during a public controversy over the legitimacy of influential technical claims, along with their implications for the medical treatment of breast cancer. Wynn's (2012) book explores interrelationships among rhetoric, mathematics, and biological science, providing a suggestive exemplar for studies of invention that center on arguments that worked to establish and transform sciences in a situated and historical context. All three alert us to the choices made and deferred that produced the arguments, the distinctive perspectives that those arguments warranted, and the questions those perspectives were adduced to resolve through securing the adherence of audiences - analytical outcomes that also mark neo-classical studies of argumentation, though generated with much less emphasis on the telltale nomenclature of classical invention.

One fertile but untilled area for examining argumentation about STM is the study of public claims-making in the social construction of social

${ }^{2}$ McGuire \& Melia's (1989) influential paper is at least partly responsible for obscuring that concept's critical utility in RSSTM. Their "modest realism" was warranted by a specific reading of recalcitrance that they used to chasten rhetoricians for their "rampant rhetoricism," purportedly restoring proper proportional order to rhetorical studies of science by demarcating where those studies would lack analytical and critical purchase. It turns out, though, that the realism of Burke's recalcitrance is of a different and more encompassing order than the narrow realist version McGuire and Melia assigned to the term (Prelli, Anderson, \& Althouse, 2011).

${ }^{3}$ For a suggestive study of this sort of criticism, see Webber (2011). 
problems. Sociologists (Adorjan, 2011; Andreas \& Greenhill, 2010; Best, 1990; Gusfield, 1981; Perrin \& Miller-Perrin, 2011; Waidzunas, 2012) developed this area of study, but rhetoricians are well equipped to contribute studies of their own. For example, Best (2013)-a major leader and initiator of work in the area-followed Gusfield (1981) in discussing medical reframing of otherwise moral or political problems, as instanced by the phobia label ("homophobia," "Islamophobia"), to construct social problems in terms not warranted by formal psychiatric categorization and diagnosis. Best's use of Toulmin's argument model to guide his work intersects with the work of rhetoricians who also turn to that model or related precepts. Analyses that identify and discriminate among selected and discarded "warrants" or other elements of argument during the process of invention and examine how arguments so produced constrained the thought and actions of those who became audience to them are quite common in rhetorical studies. Moreover, there is one distinctive but complementary point of entry for rhetoricians of STM who may want to participate in this area of scholarly work. Rather than focus on public claims-making about social problems involving STM, rhetoricians could pursue this related question: How were the evidence, concepts, values, or methods adduced as "settling" or "authoritative" STM in claims-making about specific social and other public problems generated in the first place ${ }^{4}$ Rhetorical analysis of the argumentation that generated the resources of STM for public claims-making about particular problems can disclose inventional decisions that produced alternatively argued positions, differentiate among those positions according to issues or questions addressed or foreclosed, and assess how and why some positions ultimately appeared in public and policy making discourses while others remained concealed from public view-with, of course, particular attention to consequences for public understanding of the problems framed.

Regardless of whether inventional decisions and practices are examined from the vantage of dramatism, argumentation, or some other approach, an area of RSSTM that is sure to generate varied and extensive work in the years ahead is the use of graphics and other visuals or, more generally, rhetorical displays, in generating, establishing, or promoting perspectives (Prelli, 2006a). Harmon and Gross's forthcoming book, What One Picture is Worth, offers a general theory of visual communication within science that is grounded in concepts drawn from the psychological sciences that will garner much attention (see also Gross, 2009a,b). There also are extant rhetorical analyses (e.g., Gibbons, 2007; Prelli, 2006b) relevant to invention and deployment of graphics and other visual representations. Examination of graphics and other visuals in argumentation before technical, public, or both kinds of audience sets a very fertile theme for future work, but there also remain other dimensions

\footnotetext{
${ }^{4}$ For an example of a technical controversy that remains largely concealed behind public claims-making about the social problem of violence against women that contributed to passage of the Violence Against Women Act, see my study (2005) of the controversy between "family violence" and "violence against women" researchers.
} 
of rhetorical display that have garnered little attention in RSSTM. For instance, the so-called climate change "hoax," purportedly discovered in climate scientists' emails, could upon closer examination turn out to be no more than exposing to public view the routine inventional decisions about how best to display data before professional peers. That sort of decision takes us to the performative dimensions of rhetorical displayenactments, exhibitions, demonstrations-before audiences. Ochs and her colleagues' naturalistic studies, particularly of physicists' viewgraphs and rehearsals of their use for subsequent presentation before professional peers, offer one suggestive line of inquiry for rhetoricians who seek to contribute studies of the invention and enactment of performances of or about STM (Ochs, Gonzales, \& Jacoby, 1996, 1994; Ochs \& Jacoby, 1997). ${ }^{5}$

The second promising line of inquiry for future work in RSSTM is the identification, analysis, and criticism of commonplaces. By commonplaces, I mean static and opaque words and locutions that range from the taken-for-granted if not exceedingly banal-what Jacques Ellul (1968) characterized as "the excrement of society"-to often repeated and typically unquestioned expressions that evoke powers of attraction and repulsion-what Richard Weaver (1970) called, respectively, god and devil terms. Commonplaces that draw their authority from association with purported fields of expertise are varied and extensive and, thus, provide rhetoricians with a never-ending array of possible foci for critical inquiry. Much public discourse betrays a naïve realism that evokes such terms and locutions as though they designated concrete realities. Just look around. Nearly every day at colleges and universities we hear worshipful invocation of the new commonplaces of higher education"innovation," "transformation," "change," "engagement," "success"-that however ill-defined or poorly elaborated, have become established as warrants for profiteers to sell services to achieve them "efficiently" or "cost-effectively." As though that is not bad enough, the commonplaces are adduced as though they are the inventions of authoritative scholarship and research. For instance, a recent university's promotional flyer extolled "creative disruption" as something "scholars" now inform us about, oblivious to its origins as the invention of criminal junk-bond king Michael Milken (Christensen \& Eyring, 2011, pp. 207-208). College and university administrators nonetheless often knowingly seize upon that particular new commonplace as an exciting new technique for "reinventing" higher education. Thus, "innovation" is achieved by disrupting presumably outdated institutional arrangements that feature face-to-face instruction, tenured faculty, academic departments, and the very disciplines that legitimize those departments as authoritative custodians of curricular and other facets of higher education. The new commonplaces of higher education are part of a debased rhetoric of expertise and authority left largely unchallenged. Rhetoricians of STM, by virtue of their training in rhetorical perspective, professional disposition

${ }^{5}$ The terms "exhibition" and "demonstration" also denote manifestations of display of rhetorical interest other than the sort of face-to-face performances discussed here. These include, to take one example, the design and arrangement of displays at science museums and exhibitions. 
and experience, and inclination toward fairness and transparency, are well positioned to unmask these pretenders and, thereby, work to restore a greater level of reason in deliberations about higher education and other matters of public importance.

Public discourse involving matters of STM in general is replete with expert commentaries and assertions presumably authorized as somehow addressing, if not settling, matters of public interest. Those commentaries range from daily interpretations of why the stock market gained or declined a few points and recitations of alleged facts about "entitlements" in relation to the national deficit, through representations of the surveilling powers of drone technology and the accuracy and precision of its usage in conducting missile strikes, to categorization of various maladies of body and mind along with scales for measuring them. All are the result of inventional decisions that, necessarily, conceal alternative perspectives from public view. Disclosing the implications of those inventional decisions for public understanding of the problems they allegedly confront and the range of remedies purportedly available to them would make a distinctive extension of RSSTM that could have social and/or political consequences.

I close with the third line of inquiry, captured by this question: How do RSSTM relate to cross-disciplinary work with colleagues in other fields, including work with scientists and researchers on projects that predominantly do STM? "Interdisciplinarity" surely is among the new commonplaces at today's colleges and universities, but as with most commonplaces it can evoke a range of different associations if left undefined. Our colleagues in the sciences readily associate "disciplines" with scientific specialty areas. Thus, an environmental science or sustainability science project is "interdisciplinary" when it brings together a water person, a wildlife person, a soils person, a forestry person, and so on, with sociologists and policy analysts perhaps added on-especially if they, too, capture the human dimensions of "system" studies in the form of abstract mathematical and statistical metonyms called data. At a general level, though, all share a similarly scientific orientation. Must rhetoricians, then, exhibit identification with that orientation as the price of participation? Some RSSTM surely could only benefit from learning, if not conducting, statistical analyses. But rhetorical studies as a discipline is not distinguished by efforts to secure representative samples for testing hypotheses but, rather, through use of a well-chosen sample of one, the "representative anecdote" or case study whose detailed analysis affords larger-scaled understandings of situated, contextual meanings not accessible to de-contextualized, more abstract, modes of analysis. Rhetoricians do learn and apply productively qualitative social science methods to augment their work, but content analysis, interviews, and ethnography do not distinguish what rhetoricians bring uniquely to crossdisciplinary projects.

What distinguishes RSSTM is a rhetorical perspective. Rhetoricians study selectivity in the enactment of perspective toward specific situated problems, regardless of the precepts they choose to guide their analyses. Disclosing selections made and discarded unlocks the partiality of perspectives adduced and how those selections operate to induce or 
warrant adherence from those who become audience to them. A rhetorical perspective toward STM, then, is oriented toward situated choice making, with its best and most distinctive insights always about the particular case. Disclosing the inventional operations that generate perspectives, distinguishing among the alternative perspectives brought into contact, and assessing implications for those who become audience to them are among the analytical outcomes of distinctively rhetorical approaches. Those analytical outcomes furnish materials for criticism as well: reasoned judgments about what does and does not work, or what is or is not worthwhile. After all, rhetorical studies remain among the humanities, so criticism, as well as analysis, remains a chief task for rhetoricians. These qualities of a peculiarly rhetorical perspective distinguish rhetorical studies conceptually from all other disciplines and do so in language that is readily communicable among ourselves, our colleagues in other fields (including especially those working in STM), our students, and the public.

\section{References}

Adorjan, M. (2011). The lens of victim contests and youth crime stat wars. Symbolic Interaction, 34, 552-573.

Anderson, F. D., \& Prelli, L. J. (2001). Pentadic cartography: Mapping the universe of discourse. Quarterly Journal of Speech, 87, 73-95.

Andreas, P., \& Greenhill, K. M. (Eds.) (2010). Sex, drugs, and body counts: The politics of numbers in global crime and conflict. Ithaca, NY: Cornell University Press.

Beck, C. T. (2006). Pentadic cartography: Mapping birth trauma narratives. Qualitative Health Research, 16, 453-466.

Best, J. (1990). Threatened children: Rhetoric and concern about child victims. Chicago, IL: University of Chicago Press.

Best, J. (2013). Social problems (second edition). New York: Norton.

Burke, K. (1969). The four master tropes: appendix D. In Grammar of Motives (pp. 503-517). Berkeley, CA: University of California Press.

----. (1984a). Attitudes toward history (third edition). Berkley, CA: University of California Press.

----. (1984b). Permanence and change: An anatomy of purpose (third edition). Berkeley, CA: University of California Press.

Campbell, J. A., \& Benson, K. R. (1996). The rhetorical turn in science studies. Quarterly Journal of Speech, 82, 74-109.

Christensen, C, M., \& Eyring, H. J. (2011). The innovative university: Changing the DNA of higher education from the inside out. San Francisco, CA: Jossey-Bass.

Ellul, J. (1968). A critique of the new commonplaces. New York: Knoff.

Fahnestock, J. (1999). Rhetorical figures in science. New York: Oxford University Press. 
----. (2005a). Rhetoric in the age of cognitive science. In R. Graff, A. E. Walzer, \& J. M. Atwill (Eds.), The viability of the rhetorical tradition (pp. 159-79). Albany: State University of New York Press.

----. (2005b). The rhetoric of the natural sciences. In A. A. Lunsford, K. H. Wilson, and R. A. Eberly (Eds.), The SAGE handbook of rhetorical studies (pp. 175-95). Los Angeles, CA: Sage.

Gibbons, M. G. (2007). Seeing the mind in the matter: Functional brain imagery as framed visual argument. Argument and Advocacy, 43, 175-188.

Graham, S. S., \& Herndl, C. G. (2011). Talking off-label: The role of stasis in transforming the discursive formation of pain science. Rhetoric Society Quarterly, 41, 145-167.

Gross, A. G. (1990). The rhetoric of science. Cambridge: Cambridge University Press.

----. (2009a). Presence as a consequence of verbal-visual interaction: A theoretical approach. Rhetoric Review, 28, 265-284.

----. (2009b). Toward a theory of verbal-visual interaction: The example of Lavoisier. Rhetoric Society Quarterly, 39, 147-169.

Gusfield, J. R. (1981). The culture of public problems: Drinking-driving and the symbolic order. Chicago, IL: University of Chicago Press.

Harmon, J., \& Gross, A. G. (Forthcoming). What one picture is worth. Chicago, IL: University of Chicago Press.

Hartelius, E. J. (2012). Revisiting Vico's pedagogy of invention: The intellectual entrepreneurship pre-graduate school internship. Quarterly Journal of Speech, 98, 153-177.

Keränen, L. (2010). Scientific characters: Rhetoric, politics, and trust in breast cancer research. Tuscaloosa: University of Alabama Press.

Kneupper, C. W., \& Anderson, F. D. (1980). Uniting wisdom and excellence: The need for rhetorical invention. Quarterly Journal of Speech, 66, 313-326.

Lynch, J. (2011). What are stem cells? Definitions at the intersection of science and politics. Tuscaloosa, AL: University of Alabama Press.

McGuire, J. E. and Melia, T. (1989). Some cautionary strictures on the writing of the rhetoric of science. Rhetorica, 7, 87-99.

Meisenbach, R. J., Remke, R. V., Buzzanell, P. M., \& Liu, M. (2008). "They allowed": Pentadic mapping of women's maternity leave discourse as organizational rhetoric. Communication Monographs, $75,1-24$.

Moore, M. P. (1993). Constructing irreconcilable conflict: The function of synecdoche in the spotted owl controversy. Communication Monographs, 6o, 258-74.

----. (1996). The cigarette as representational ideograph in the debate over environmental tobacco smoke. Communication Monographs, $64,47-64$. 
----. (2003). Making sense of salmon: Synecdoche and irony in a natural resource crisis. Western Journal of Communication, 67, 74-96.

----. (2009). The Union of Concerned Scientists on the uncertainty of climate change: A study of synecdochic form. Environmental Communication, 3, 191-205.

Nelson, J. S. (1987). Seven rhetorics of inquiry: A provocation. In J. S. Nelson, A. Megill, and D. N. McCloskey (Eds.), The rhetoric of the human sciences: Language and argument in scholarship and public affairs (pp. 407-434). Madison: University of Wisconsin Press.

Ochs, E., Gonzales, P., \& Jacoby, S. (1996). "When I come down I'm in the domain state": Grammar and graphic representation in the interpretive activity of physicists. In E. Ochs, E. Schegloff, and S. Thompson (Eds.), Interaction and grammar (pp. 328-69). Cambridge: Cambridge University Press.

Ochs, E., Jacoby, S., \& Gonzales, P. (1994). Interpretive journeys: How physicists talk and travel through graphic space. Connections, 1, 151171.

Ochs, E., \& Jacoby, S. (1997). Down to the wire: The cultural clock of physicists and the discourse of consensus. Language in Society, 26, 127.

Perrin, R. D., \& Miller-Perrin, C. L. (2011). Interpersonal violence as social construction: The potentially undermining role of claims making and advocacy statistics. Journal of Interpersonal Violence, 26, 3033-3049.

Prelli, L. J. (1989). A rhetoric of science: Inventing scientific discourse. Columbia: University of South Carolina Press.

----. (2004). Topical analysis and the problem of judgment in environmental disputes. In T. R. Peterson (Ed.), Green talk in the White House: The rhetorical presidency encounters ecology (pp. 233257). College Station, TX: Texas A\&M University.

----. (2005). Stasis and the problem of incommensurate communication: The case of spousal violence research. In R. A. Harris, (Ed.), Rhetoric and incommensurability (pp. 294-333). West Lafayette, IN: Parlor Press.

----. (Ed.). (2006a). Rhetorics of display. Columbia: University of South Carolina Press.

----. (2006b). Visualizing a bounded sea: A case study in rhetorical taxis. In L. J. Prelli (Ed.), Rhetorics of display (pp. 90-120). Columbia: University of South Carolina Press.

----(2011). Master tropes and the Pre-figuration of plant ecology: A study in the invention of a science. A paper presented at the annual meeting of the National Communication Association. New Orleans, LA.

Prelli, L. J., Anderson, F. D., \& Althouse, M. T. (2011). Kenneth Burke on recalcitrance. Rhetoric Society Quarterly, 41, 97-124.

Schiappa, Edward. (1993). Burkean tropes and Kuhnian science: A social 
constructionist perspective on language and reality. Journal of Advanced Composition, 13, 401-22.

Simons, H. W. (Ed.). (1990). The rhetorical turn: Invention and persuasion in the conduct of inquiry. Chicago, IL: University of Chicago Press.

Smith, J. M. (1996). Geographical rhetoric: Modes and tropes of appeal. Annals of the Association of American Geographers, 86, 1-20.

Tietge, D. J. (1988). The role of Burke's four master tropes in scientific expression. Journal of Technical Writing and Communication, 28, 317-324.

Waidzunas, T. (2012). Young, gay, and suicidal: Dynamic nominalism and the process of defining a social problem with statistics. Science, Technology, \& Human Values, 37, 199-225.

Walsh, L. (2009). Visual strategies to integrate ethos across the "is/ought" divide in the IPCC's Climate Change 2007: Summary for policy makers. Poroi, 6(2), 33-61.

----. (2010). The common topoi of STEM discourse: An apologia and methodological proposal, with pilot survey. Written Communication, 27, 120-156.

Weaver, R. M. (1970). Ultimate terms in contemporary rhetoric. In R. L. Johannesen, Strickland, R., and R. T. Eubanks (Eds.), Language is sermonic: Richard M. Weaver on the nature of rhetoric (pp. 87-112). Baton Rouge, LA: Louisiana State University Press.

Webber, J. (2012). Towards public professionalism: A pentadic intervention in debate between the Common Core Standards Initiative (CCSI) and the National Council of Teachers of English (NCTE) (Unpublished doctoral dissertation). Durham, NH: University of New Hampshire.

White, H. (1973). Metahistory: The historical imagination in nineteenthcentury Europe. Baltimore, MD: Johns Hopkins Press.

----. (1978). Tropics of discourse: Essays in cultural criticism. Baltimore, MD: Johns Hopkins Press.

----. (1999). Figural realism: Studies in the mimesis effect. Baltimore, MD: Johns Hopkins University Press.

Wynn, J. (2012). Evolution by the numbers: The origins of mathematical argument in biology. Anderson, SC: Parlor Press. 